\title{
Antioxidant and Cytotoxic Effects and Identification of Ophiocordyceps sinensis Bioactive Proteins Using Shotgun Proteomic Analysis
}

\section{Boon-Hong Kong ${ }^{1} \odot$, Chee-Sum Alvin Yap', Muhammad Fazril Mohamad Razif'®, Szu-Ting $\mathrm{Ng}^{2}$, Chon-Seng $\operatorname{Tan}^{2}$ and Shin-Yee Fung ${ }^{1,3,4 *} \odot$}

'Medicinal Mushroom Research Group, Department of Molecular Medicine, Faculty of Medicine, University of Malaya, 50603 Kuala Lumpur, Malaysia

2LiGNO Biotech Sdn. Bhd., Jalan Perindustrian Balakong Jaya 2/2, Taman Perindustrian Balakong Jaya 2, 43300 Balakong Jaya, Selangor, Malaysia

${ }^{3}$ Centre for Natural Products Research and Drug Discovery (CENAR), University of Malaya, 50603 Kuala Lumpur, Malaysia

${ }^{4}$ University of Malaya Centre for Proteomics Research (UMCPR), University of Malaya, 50603 Kuala Lumpur, Malaysia

Received: 21 January 2021 Accepted: 28 April 2021

\section{(i)}

*Corresponding author:

Phone: +603 79675745

Fax: +603 79674957

E-mail: syfung@um.edu.my, syfung@ummc.edu.my

\section{SUMMARY}

Research background. Ophiocordyceps sinensis, a highly valued medicinal fungus, is close to extinction due to overexploitation. Successful cultivation of $O$. sinensis fruiting body $\left(\mathrm{OCS}^{\circ}{ }^{\circ}\right)$ shows that the cultivar has a promising nutritional value and numerous bioactive compounds. Antioxidant and antiproliferative properties and biologically active proteins of the $\mathrm{OCS}_{2}{ }^{\circledR}$ are investigated for possible development into nutraceuticals.

Experimental approach. The chemical composition of the $\mathrm{OCS}^{\circ} 2^{\circledR}$ cold water extract was determined, and the antioxidant activities were examined using ferric reducing, DP$\mathrm{PH}^{\cdot}$ and $\mathrm{O}_{2}{ }^{-}{ }^{-}$scavenging assays. Tetrazolium dye (MTT) cytotoxic assay was performed to assess the antiproliferative activity of the extract. Bioactive proteins in the active fraction of the extract were identified using liquid chromatography (LC) and tandem-mass spectrometry (MS/MS).

Results and conclusions. The $\mathrm{OCS}^{\circ} 2^{\odot}$ extract exhibited strong $\mathrm{O}_{2}{ }^{-}$scavenging (expressed as Trolox equivalents $(18.4 \pm 1.1) \mathrm{mol} / \mathrm{g}$ ) and potent cytotoxic activities against adenocarcinomic human alveolar basal epithelial (A549) cells $\left(I C_{50}=(58.2 \pm 6.8) \mu \mathrm{g} / \mathrm{mL}\right)$. High molecular mass polysaccharides, proteins and protein-polysaccharide complexes could have contributed to the antioxidant and cytotoxic selectivity of the OCSO2 ${ }^{\circledR}$. LC-MS/MS analysis identified several potential cytotoxic proteases and an oxalate decarboxylase protein which may exhibit protection effects on kidneys.

Novelty and scientific contributions. The findings demonstrate the potential of $\mathrm{OCSO}_{2}{ }^{\circledR}$ to be developed into functional food due to its promising superoxide anion radical scavenging capacity, cytotoxic effect and presence of biopharmaceutically active proteins.

Key words: Ophiocordyceps sinensis, antioxidant activity, cytotoxic effect, bioactive proteins, protein-polysaccharide complexes

\section{INTRODUCTION}

Ophiocordyceps sinensis or Cordyceps sinensis (in Chinese known as Dong Chong Xia Cao or 'worm in winter and grass in summer') is an insect-parasitizing fungus from the Ascomycetes family (1). $O$. sinensis is a traditional Tibetan, Chinese and Indian medicinal fungus found in Tibetan Plateau, China and Indian Himalaya (2). This fungus is commonly used as a functional food to reduce inflammation in the body, to improve respiratory system, libido and erectile function, and to treat liver, cardiovascular and chronic kidney diseases $(3,4)$. It is also used as a type of herbal tonic to restore energy and promote general health $(3,5)$.

Many scientific studies have shown that $O$. sinensis contains numerous bioactive compounds such as cordycepin, polysaccharides, sterol-type compounds, unsaturated fatty acids and peptides. These compounds exert various biopharmacological activities including anti-inflammatory, immunomodulatory, antiproliferative, anti-aging and antioxidant, as well as protective effects on the respiratory, hepatic, renal and cardiovascular systems (6). The use of $O$. sinensis as a medicinal health supplement is a global trend. However, natural production of this fungus is limited, and overexploitation to meet high market demand has led to near extinction of the species (7). Efforts in cultivation of $O$. sinensis using 
artificial media have been the most promising approach for mass production of $O$. sinensis for development into nutraceuticals. The artificially cultured fruiting bodies, mycelia and fermented mycelial products have been shown to possess biopharmaceutical properties comparable with the wild type, including antioxidant, anti-inflammatory, antitumour, immunomodulatory and anti-hyperglycaemic activities and the enhancement of neuromuscular activity (8-11).

Recent studies have demonstrated that a laboratory-cultured 0 . sinensis fruiting body $\left(\mathrm{OCSO}^{\circledR}\right)$ by LiGNO Biotech Sdn. Bhd. (Selangor, Malaysia) is safe for consumption. No toxic effects have been reported from an oral administration of $1000 \mathrm{mg} / \mathrm{kg}$ of $\mathrm{OCS} 02^{\circledR}$ in rats in subacute toxicity assessment and no heavy metal was detected in the sample $(12,13)$. It is rich in proteins and minerals, and contains high amounts of bioactive compounds including cordycepin, amino acids and glucans (13). Therefore, it is important to investigate the biopharmaceutical properties of $\mathrm{OCS}_{2}{ }^{\circledR}$ to support the development of this strain into functional food and nutraceutical. Previous study showed that the $\mathrm{OCSO}{ }^{\circledR}{ }^{\circledR}$ cold aqueous extract possessed immunomodulatory properties attributed to its polysaccharide and protein contents (14). Herein, we aim to further examine the antioxidant and antiproliferative properties of $\mathrm{OCS}_{2}{ }^{\circledR}$ water extract, and to identify the potential bioactive proteins in it. The biopharmaceutical active proteins found in $\mathrm{OCS} 22^{\circledR}$ could play a role as potential new drug candidates.

\section{MATERIALS AND METHODS}

\section{Fruiting body $\mathrm{OCS}^{\circledR}{ }^{\circledR}$ and extract preparation}

The Ophiocordyceps sinensis fruiting body $\left(\mathrm{OCSO}^{\circledR}{ }^{\circledR}\right)$ was cultured using solid-state fermentation with rice-based medium as a substrate (LiGNO Biotech Sdn. Bhd., Selangor, Malaysia). This cultivated species was authenticated by its partial small subunit ribosomal gene (12). A mixture of $30 \mathrm{~g}$ freeze-dried OCS02 ${ }^{\circledR}$ powder and $600 \mathrm{~mL}$ distilled water was stirred at $4{ }^{\circ} \mathrm{C}$ for $24 \mathrm{~h}$ to extract the heat-labile substances. The unextracted materials were pelleted using a refrigerated centrifuge $\left(8000 \times g, 4{ }^{\circ} \mathrm{C}, 30 \mathrm{~min}\right.$; Sorvall Biofuge Primo R, Thermo Scientific, Waltham, MA, USA), while the water extract was filtered using a grade 1 filter paper (Whatman ${ }^{\circledast}$, GE Healthcare Bio-Sciences AB, Uppsala, Sweden). The freeze-dried cold water extract was kept at $-20^{\circ} \mathrm{C}$ and dissolved in distilled water for further analysis.

\section{Fractionation of $\mathrm{OCSO} 2^{\circledR}$ cold water extract}

The cold water extract of OCSO $2^{\circledR}$ was fractionated using gel filtration (Sephadex ${ }^{\mathrm{TM}}$ G-50; GE Healthcare Life Sciences, Marlborough, MA, USA) column chromatography $(I=40 \mathrm{~cm}$, $d=2.5 \mathrm{~cm}$ ). The fractions were eluted using $0.05 \mathrm{M}$ ammonium acetate buffer (Merck, Darmstadt, Germany). Fractions of three different molecular masses (low, medium and high) were collected according to protein and carbohydrate peak profiles. Bradford's assay was performed to determine the protein content of the fractions (15). Carbohydrate content was estimated using phenol sulfuric acid assay (16).

\section{Isolation of proteins from the high molecular mass fraction}

Proteins were precipitated from the high molecular mass (HMM) fraction using ammonium sulfate (Sigma-Aldrich, Merck, St Louis, MO, USA). The HMM fraction was dissolved in water, ammonium sulfate was gradually added until $100 \%$ saturation was reached, followed by continuous stirring for an hour at $4{ }^{\circ} \mathrm{C}$. The precipitated proteins and non-protein component (supernatant) were retrieved by centrifugation and desalted using the Sartorius centrifugal concentrator, Vivaspin $^{\circledast}$ 15R (Göttingen, Germany) of molecular mass cut-off value of $5 \mathrm{kDa}$.

\section{Total phenolic content}

The phenolic content of $\mathrm{OCSO}^{\circledR}{ }^{\circledR}$ cold water extract and Sephadex-G50 fractions was determined using Folin-Ciocalteu assay (17). Briefly, Folin-Ciocalteu's phenol reagent (Merck), 1:10 (500 $\mu \mathrm{L})$, was mixed with a sample $(10 \mu \mathrm{L})$ and incubated at ambient temperature $\left(\sim 22^{\circ} \mathrm{C}\right)$ for $5 \mathrm{~min}$. A volume of $350 \mu \mathrm{L}$ sodium carbonate $(115 \mu \mathrm{g} / \mathrm{mL})$ was pipetted into the mixture and further incubated for $2 \mathrm{~h}$. Gallic acid (Sigma-Aldrich, Merck) at concentrations from 20 to $200 \mu \mathrm{g} / \mathrm{mL}$ was used as standard. The absorbance values (765 nm) were recorded using a plate spectrophotometer (Bio-Rad model 680; Hercules, CA, USA).

\section{Antioxidant assays}

Antioxidant activity of $\mathrm{OCS} 02^{\circledR}$ cold water extract and its fractions was assessed using ferric reducing antioxidant power (FRAP) (18) and superoxide anion radical $\left(\mathrm{O}_{2}{ }^{--}\right)$scavenging (19) assays. The 1,1-diphenyl-2-picrylhydrazyl radical (DPPH') scavenging capacity was assessed using the method of Cos et al. (20), with slight adjustments. A volume of $25 \mu \mathrm{L}$ sample (0-16 mg/mL) was mixed with $150 \mu \mathrm{L}$ DPPH (Sigma-Aldrich, Merck) solution ( $40 \mu \mathrm{g} / \mathrm{mL}$ in methanolic solution). The sample was then incubated for $30 \mathrm{~min}$ in the dark $\left(20-22^{\circ} \mathrm{C}\right)$, and the absorbance was measured at $515 \mathrm{~nm}$. Different concentrations $(0-2 \mathrm{mg} / \mathrm{mL}$ ) of Trolox (Sigma-Aldrich, Merck) were used to generate a standard curve.

\section{Cell culture and MTT cytotoxicity assay}

American Type Culture Collection (ATCC ${ }^{\circledR}$, Manassas, VA, USA) of human breast (MCF7 and MDA-MB-231), lung (A549) and prostate (PC3) adenocarcinoma cell lines, and human normal lung (NL20) cell line were used for this study. Roswell Park Memorial Institute (RPMI) 1640 medium (Nacalai Tesque, Kyoto, Japan) was used to culture MCF7, PC3 and A549 cell lines. MDA-MB-231 and NL20 cell lines were maintained in Dulbecco's modified Eagle's medium (DMEM) (Nacalai Tesque) and Ham's F12 medium (Lonza, Basel, Switzerland), 
respectively. All the media contained $10 \%$ foetal bovine serum and cells were allowed to proliferate in an incubator at $37^{\circ} \mathrm{C}$ with $95 \%$ humidity and $5 \% \mathrm{CO}_{2}$.

To examine the cytotoxicity effect of $\mathrm{OCS}_{2}{ }^{\circledR}$ cold water extract and its fractions, cells seeded overnight (at optimal density) in 96-well microplate were treated with various concentrations $(15.6-500 \mathrm{mg} / \mathrm{mL})$ of samples $(200 \mu \mathrm{L})$ for $72 \mathrm{~h}$. After $72 \mathrm{~h}$ of treatment, MTT reagent was added into each well at a final concentration of $0.45 \mu \mathrm{g} / \mathrm{mL}$ and incubated for $4 \mathrm{~h}$ at $37^{\circ} \mathrm{C}$. The mixture of spent medium and MTT reagent was discarded, and dimethyl sulfoxide (DMSO) $(200 \mu \mathrm{L})$ was used for dissolution of purple formazan crystals prior to measurement of the absorbance values $(570 \mathrm{~nm})$. Concentration of the extract and fractions that was required to inhibit $50 \%$ of cell proliferation $\left(I_{50}\right)$ was calculated from the curves plotted using the cell viability percentage over the tested sample concentrations.

\section{Identification of proteins using LC-MS/MS}

Proteins isolated from the HMM fraction were resolved with sodium dodecyl sulphate-polyacrylamide gel electrophoresis (SDS-PAGE) under reducing conditions. The separated protein bands were excised into $10 \mathrm{gel}$ sections, where the gel sections were destained, reduced with dithiothreitol, alkylated with iodoacetamide and tryptic digested with trypsin protease (Thermo Scientific ${ }^{\mathrm{TM}}$, Pierce ${ }^{\mathrm{TM}}$, Rockford, IL, USA) (21). Analysis was performed using an Agilent 1260 HPLC-Chip/MS Interface, coupled with Agilent 6550 Accurate-Mass Q-TOF LC/MS (Agilent Technologies, Santa Clara, (A, USA), following the protocol as described previously $(21,22)$. The National Center for Biotechnology Information (NCBI) database of Ophiocordycipitaceae (non-redundant) was used for mass spectra searches that were performed using the Agilent Spectrum Mill MS Proteomics Workbench software packages. The spectrum mill settings applied including molecular ion $\left(\mathrm{MH}^{+}\right)$scan (100-3200 Da), complete carbamidomethylating of cysteines, peptides and protein scores greater than 6 and 20, respectively, scored peak intensity above $60 \%$, and the significant number of distinct peptides is greater than or equal to two. Relative protein percentage was determined using the formula:

$$
w(\text { protein })=\left(I_{\mathrm{m}} / I_{\mathrm{t}}\right) \cdot I_{\mathrm{r}} \cdot 100
$$

where $I_{\mathrm{m}}$ and $I_{\mathrm{t}}$ are mean and total peptide spectral intensity of a protein and $I_{r}$ is a relative intensity of each gel section in the protein lane estimated by densitometry using Thermo Scientific $^{\mathrm{TM}}$ Pierce $^{\mathrm{TM}}$ mylmage Analysis ${ }^{\mathrm{TM}}$ Software, Rockford, IL, USA.

\section{Statistical analysis}

All data are expressed as mean value \pm standard deviation (S.D.). Differences between the mean values in the experiment groups analysed using one-way analysis of variance (ANOVA) and Tukey's HSD post hoc test (IBM SPSS Statistics v. 22) (23) were considered statistically significant at $p<0.05$.

\section{RESULTS AND DISCUSSION}

\section{Antioxidant activity}

Antioxidant activities including ferric reducing power, $\mathrm{DPPH}^{\circ}$ and $\mathrm{O}_{2}{ }^{-}{ }^{-}$scavenging assay were performed on the Ophiocordyceps sinensis fruiting body $\left(\mathrm{OCS}^{\circledR}{ }^{\circledR}\right)$ cold water extract and its fractions of different molecular masses (Table 1). The cold water extract demonstrated low FRAP and DPPH scavenging capacities compared to rutin and quercetin (positive controls). However, the capability of the $\mathrm{OCS}^{\circ} 2^{\circledR}$ cold water extract to scavenge DPPH expressed as Trolox equivalents is ten times higher $(0.015 \mathrm{mmol} / \mathrm{g})$ than water extracts from the reported 0 . sinensis and other mushrooms (0.0013$0.0049 \mathrm{mmol} / \mathrm{g}$ ) (24). The extract also demonstrated higher superoxide radical scavenger capability $(18.4 \mathrm{mmol} / \mathrm{g})$ than other reported Lignosus spp. mushrooms $(9.61-9.90 \mathrm{mmol} / \mathrm{g}$ ) $(25,26)$. Three different molecular mass (HMM, MMM and LMM) fractions of the $\mathrm{OCS} 02^{\circledR}$ cold water extract collected from Sephadex G-50 fractionation also demonstrated weak iron(III) reducing and DPPH ${ }^{*}$ scavenging activities, with the HMM fraction as the weakest DPPH' scavenger. However, this

Table 1. Chemical composition and antioxidant activity of the Ophiocordyceps sinensis fruiting body $\left(\mathrm{OCSO2}^{\circledR}\right)$ cold water extract and its fractions

\begin{tabular}{|c|c|c|c|c|c|c|}
\hline \multirow{3}{*}{ Sample } & \multicolumn{3}{|c|}{ Chemical composition } & \multicolumn{3}{|c|}{ Antioxidant activity } \\
\hline & \multirow{2}{*}{$w($ protein)/\% } & \multirow{2}{*}{$w($ carbohydrate) $/ \%$} & \multirow{2}{*}{$\begin{array}{c}w(\text { phenolics as } \\
\mathrm{GAE}) /(\mathrm{mg} / \mathrm{g})\end{array}$} & \multirow{2}{*}{$\mathrm{FRAP} /(\mathrm{mmol} /(\mathrm{min} \cdot \mathrm{g}))$} & \multicolumn{2}{|c|}{$\mathrm{TEAC} /(\mathrm{mmol} / \mathrm{g})$} \\
\hline & & & & & DPPH & Superoxide anion \\
\hline CWE & $(2.1 \pm 0.3)^{a}$ & $(41.5 \pm 6.1)^{a}$ & $(6.7 \pm 0.6)^{a}$ & $(0.0022 \pm 0.0002)^{\mathrm{a}}$ & $(0.0153 \pm 0.0001)^{\mathrm{a}}$ & $(18.4 \pm 1.1)^{\mathrm{a}}$ \\
\hline HMM & $(3.8 \pm 0.9)^{\mathrm{a}}$ & $(80.3 \pm 9.5)^{b}$ & $(5.2 \pm 1.7)^{\mathrm{ab}}$ & $(0.0008 \pm 0.0002)^{\mathrm{a}}$ & $(0.0027 \pm 0.0007)^{\mathrm{b}}$ & $(22.6 \pm 1.9)^{b}$ \\
\hline MMM & $(3.3 \pm 1.5)^{\mathrm{a}}$ & $(28.0 \pm 5.1)^{\mathrm{a}}$ & $(14.8 \pm 0.8)^{c}$ & $(0.0031 \pm 0.0003)^{\mathrm{a}}$ & $(0.0141 \pm 0.0002)^{\mathrm{a}}$ & $(15.5 \pm 0.2)^{\mathrm{a}}$ \\
\hline LMM & n.d. & $(0.6 \pm 0.3)^{c}$ & $(3.3 \pm 0.6)^{b}$ & $(0.0008 \pm 0.0002)^{\mathrm{a}}$ & $(0.0170 \pm 0.0003)^{\mathrm{a}}$ & $(2.6 \pm 0.5)^{c}$ \\
\hline Rutin & - & - & - & $(2.6 \pm 0.11)^{\mathrm{b}}$ & $(1.265 \pm 0.005)^{c}$ & $(29.1 \pm 1.3)^{d}$ \\
\hline Quercetin & - & - & - & $(0.7 \pm 0.02)^{c}$ & $(1.214 \pm 0.003)^{d}$ & $(25.4 \pm 0.4)^{b}$ \\
\hline
\end{tabular}

Protein and carbohydrate were measured on dry mass basis. All the values were expressed as mean \pm S.D. ( $N=3$ ). Mean values in the same column with different letters in superscript are significantly different according to the analysis of variance and Tukey's HSD post hoc test $(p<0.05)$. Rutin and quercetin were used as positive controls in the antioxidant assay. CWE $=$ cold water extract, $\mathrm{HMM}=$ high molecular mass, $\mathrm{MMM}=$ medium molecular mass, $\mathrm{LMM}=$ low molecular mass, $\mathrm{n} . \mathrm{d}$.=not detected, $\mathrm{GAE}=$ gallic acid equivalents, TEAC=Trolox equivalent antioxidant capacity 
fraction was the most potent $\mathrm{O}_{2}{ }^{--}$scavenger among the fractions with the activity higher than of the crude cold water extract and comparable to the positive controls. This superoxide scavenging property is of great significance as it implies that $\mathrm{OCS}_{2}{ }^{\circledR}$ can be beneficial as an antioxidant supplement to aid in prevention of superoxide anion radical-induced oxidative stress and related diseases. The antioxidant activity of the $\mathrm{OCS}^{\circ}{ }^{\circledR}$ was not correlated with its phenolic content. For instance, MMM fraction exhibited equal to or lower $\mathrm{O}_{2}{ }^{-}$ scavenging activity than the cold water extract and HMM fraction, respectively, although it contains twice higher phenolic content (Table 1). A few studies have reported that the antioxidant activity of the $O$. sinensis is mostly contributed to polysaccharides $(27,28)$. Thus, the strong $\mathrm{O}_{2}{ }^{-}$scavenging activity of $\mathrm{OCSO}{ }^{\circledR}{ }^{\circledR}$ could be attributed to carbohydrates or polysaccharides that are abundantly present in the HMM fraction (Table 1). The synergistic effects among phenolics, proteins and protein-polysaccharide complexes could also have contributed to the antioxidant activities of the OCSO2 ${ }^{\circledR}$.

\section{Cytotoxic activity of $\mathrm{OCSO} 2^{\circledR}$ cold water extract and its fractions}

An investigation of the in vitro cytotoxicity of the $\mathrm{OCSO}^{\circledR}$ cold water extract showed that it exhibited significant cytotoxicity $\left(\mathrm{IC}_{50}=(58.2 \pm 6.8) \mu \mathrm{g} / \mathrm{mL}\right)$ against lung cancer A549 cells (Fig. 1). The extract also exerted weak cytotoxic activity against MCF7 cells with the $\mathrm{IC}_{50}=(371.0 \pm 62.0) \mu \mathrm{g} / \mathrm{mL}$, or approx. 6-fold higher than against A549 cells. Our results showed that the cold water extract was more active in inhibiting the proliferation of oestrogen-dependent MCF7 breast cancer cells than the invasive, oestrogen-independent MDA-MB-231 breast cancer cells. There were no observed effects on the MDA-MB-231 and prostate cancer PC3 cells $\left(\mathrm{IC}_{50}>1000\right.$ $\mu \mathrm{g} / \mathrm{mL}$ ). Although the cold water extract exerted good antiproliferative activity on A549 cells, it was cytotoxic to normal lung NL20 cells as well $\left(\mathrm{IC}_{50}=(42.4 \pm 2.2) \mu \mathrm{g} / \mathrm{mL}\right)$. The NL20 is an immortalised non-tumourigenic lung cell line derived from human healthy lung epithelial cells through transfection

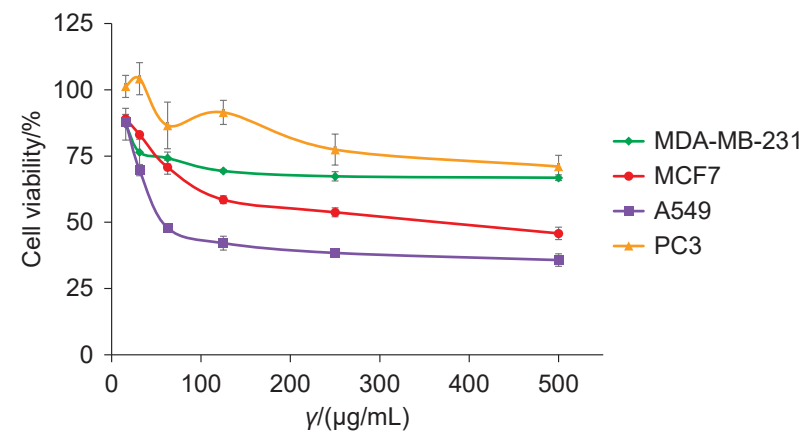

Fig. 1. Cytotoxic activity of Ophiocordyceps sinensis fruiting body $\left(\mathrm{OCS} 02^{\circledR}\right)$ cold water extract at various concentrations against MCF7, MDA-MB-231 (human breast adenocarcinoma), A549 (human lung adenocarcinoma) and PC3 (human prostate adenocarcinoma) cell lines. Values are expressed as mean \pm S.D. $(N=3)$ with SV40 large T plasmid (29). NL20 cells showed no mutations in K-ras codons, no c-myc gene amplification and activation of dominant oncogenes (30) and are commonly used as non-tumourigenic (normal lung cells) lung cell model along with A549 lung adenocarcinoma cell model (31-35). With further fractionation of the cold water extract, the isolated HMM fraction demonstrated cytotoxic selectivity towards lung cancer A549 cells with selectivity index of 1.8 ( Table 2). Yet, separated proteins and non-protein (mostly polysaccharides) components of the HMM fraction was cytotoxic to normal lung cell line (NL20), which implies the non-selective nature of the cytotoxicity of proteins and polysaccharides toward this cancer cell line. Previous reports have indicated that the polysaccharides from $O$. sinensis act on cancer cells by modulating the immune system rather than exerting direct cytotoxicity against the cancer cells $(36,37)$. A recent work (14) done using $\mathrm{OCS} 02^{\circledR}$ revealed that the $\mathrm{HMM}$ fraction consists of heteroglycans that stimulate the release of several cytokines/chemokines associated with its immunomodulator capability. Hence, this suggests that carbohydrates, the most abundant components in the HMM fraction, could act as immunomodulator associated with the antitumour effects on A549 cells.

Table 2. Cytotoxicity of Ophiocordyceps sinensis fruiting body (OCSO2 $\left.{ }^{\circledR}\right)$ cold water extract fractions against human lung adenocarcinoma and normal cell lines

\begin{tabular}{|c|c|c|c|}
\hline \multirow{2}{*}{ Sample } & \multicolumn{2}{|c|}{$1 C_{50} /(\mu \mathrm{g} / \mathrm{mL})$} & \multirow{2}{*}{$\begin{array}{l}\text { Selectivity } \\
\text { index }\end{array}$} \\
\hline & A549 & NL20 & \\
\hline HMM & $157.3 \pm 10.1$ & $279.0 \pm 70.1$ & 1.8 \\
\hline MMM & $357.3 \pm 54.5$ & $56.5 \pm 4.2$ & 0.2 \\
\hline LMM & $>1000$ & n.d. & n.a. \\
\hline HMM-P & $107.8 \pm 5.9$ & $79.4 \pm 13.0$ & 0.7 \\
\hline HMM-NP & $213.3 \pm 37.5$ & $95.3 \pm 14.1$ & 0.5 \\
\hline$\gamma($ paclitaxel $) /(\mathrm{ng} / \mathrm{mL})$ & $7.1 \pm 0.9$ & $7.6 \pm 0.5$ & 1.1 \\
\hline
\end{tabular}

$\mathrm{HMM}=$ high molecular mass, $\mathrm{MMM}=$ medium molecular mass, $\mathrm{LMM}=$ low molecular mass, $\mathrm{P}=$ protein, $\mathrm{NP}=$ non-protein, $\mathrm{A549}=$ human lung adenocarcinoma, NL20=human normal lung, n.d.=not determined, n.a. $=$ not available. Selectivity index was determined by dividing $I C_{50}$ of NL20 normal lung cells with the $\mathrm{IC}_{50}$ of the $\mathrm{A} 549$ adenocarcinoma cells. Selectivity index above 1.0 revealed that the treatment was more cytotoxic (selective) against A549 adenocarcinoma cells

\section{Determination of the protein composition of HMM by LC-MS/MS}

To date, limited studies are available for bioactive protein isolation from $O$. sinensis and their identification. Studies have shown that fungi contain potential antioxidative and cytotoxic proteins such as manganese superoxide dismutase, catalase, glutathione transferase, lectin, proteases and fungal immunomodulatory proteins (38-40). Using shotgun LC-MS/ MS analysis, this study has identified a total of 17 distinct proteins in the HMM protein fraction (Table 3 and Fig. 2). Majority ( $>50 \%)$ of the proteins, e.g. a-mannosidase, $\beta$-glucosidase A, $\beta$-1,3-glucanosyltransferase, glycoside hydrolase family 
Table 3. List of high molecular mass proteins from Ophiocordyceps sinensis fruiting body (OCSO2 $\left.{ }^{\circledR}\right)$ cold water extract identified by LC-MS/MS

\begin{tabular}{|c|c|c|c|c|c|c|c|c|c|}
\hline 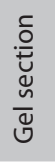 & 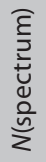 & 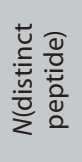 & $\begin{array}{c}\text { Distinct } \\
\text { summed } \\
\text { MS/MS } \\
\text { search } \\
\text { score }\end{array}$ & $\begin{array}{c}\text { Amino } \\
\text { acid } \\
\text { coverage/\% }\end{array}$ & $\begin{array}{l}\text { Protein } \\
\text { pl }\end{array}$ & $I_{\mathrm{m}} \cdot 10^{5}$ & $w($ protein $) / \%$ & $\begin{array}{c}\text { Database } \\
\text { accession no. }\end{array}$ & Protein name \\
\hline S1 & 2 & 2 & 31.80 & 2.1 & 6.26 & 1.23 & 0.65 & 799247974 & Hypothetical protein HIM_04044 \\
\hline S1 & 2 & 2 & 30.12 & 2.2 & 5.91 & 5.10 & 2.70 & 908394288 & a-mannosidase \\
\hline S1 & 2 & 2 & 28.97 & 3.1 & 6.30 & 1.05 & 0.56 & 531866672 & Glutaminase GtaA \\
\hline S1 & 2 & 2 & 25.45 & 2.2 & 4.97 & 0.93 & 0.49 & 1032877594 & WSC domain-containing protein \\
\hline S2 & 2 & 2 & 37.54 & 2.8 & 5.63 & 3.28 & 13.07 & 1261512171 & Hypothetical protein XA68_12018 \\
\hline S2 & 2 & 2 & 34.08 & 1.9 & 5.58 & 4.11 & 16.37 & 799246137 & Putative $\beta$-glucosidase $A$ \\
\hline S3 & 3 & 2 & 37.75 & 3.1 & 5.91 & 1.46 & 17.86 & 908394288 & a-mannosidase \\
\hline S4 & 4 & 3 & 54.08 & 3.8 & 6.26 & 2.12 & 0.49 & 799247974 & Hypothetical protein HIM_04044 \\
\hline S4 & 3 & 3 & 47.12 & 7.1 & 5.00 & 11.3 & 2.62 & 799246399 & Hypothetical protein HIM_05392 \\
\hline S4 & 3 & 2 & 37.00 & 6.9 & 5.06 & 2.99 & 0.69 & 1008934073 & $\beta$-1,3-glucanosyltransferase \\
\hline S4 & 2 & 2 & 28.87 & 3.0 & 5.39 & 2.51 & 0.58 & 1335267264 & a-1,2-mannosidase \\
\hline S4 & 2 & 2 & 28.30 & 2.3 & 4.46 & 21.6 & 5.01 & 908387070 & Hypothetical protein TOPH_07589 \\
\hline S5 & 6 & 6 & 100.47 & 24.1 & 6.79 & 7.52 & 1.44 & 908389224 & Transaldolase \\
\hline S5 & 6 & 5 & 70.55 & 6.3 & 5.75 & 3.48 & 0.67 & 531863817 & Peptidase M49, dipeptidyl-peptidase III \\
\hline S5 & 5 & 4 & 69.02 & 4.6 & 5.91 & 6.02 & 1.15 & 908394288 & a-mannosidase \\
\hline S5 & 3 & 3 & 47.81 & 8.2 & 6.48 & 2.34 & 0.45 & 1261512568 & Hypothetical protein XA68_11515 \\
\hline S5 & 3 & 2 & 35.49 & 5.9 & 6.20 & 2.36 & 0.45 & 799247347 & Oxalate decarboxylase \\
\hline S5 & 2 & 2 & 32.15 & 8.8 & 5.70 & 4.93 & 0.94 & 531867008 & Peptidase A1 \\
\hline S5 & 2 & 2 & 28.71 & 4.2 & 8.94 & 6.10 & 1.17 & 799249484 & Hypothetical protein HIM_02208 \\
\hline S5 & 2 & 2 & 28.45 & 2.3 & 4.46 & 26.9 & 5.13 & 908387070 & Hypothetical protein TOPH_07589 \\
\hline S5 & 2 & 2 & 26.58 & 5.1 & 6.27 & 11.9 & 2.27 & 799247067 & Subtilisin-like proteinase Spm1 \\
\hline S6 & 4 & 4 & 59.88 & 9.2 & 6.87 & 3.45 & 1.72 & 799247099 & Transaldolase \\
\hline S6 & 4 & 4 & 56.08 & 4.8 & 5.99 & 3.85 & 1.92 & 1339424435 & a-mannosidase \\
\hline S6 & 2 & 2 & 33.76 & 5.9 & 6.2 & 1.55 & 0.77 & 799247347 & Oxalate decarboxylase \\
\hline S6 & 2 & 2 & 29.11 & 1.8 & 5.65 & 5.75 & 2.87 & 1335262293 & Dipeptidyl peptidase 3 \\
\hline S7 & 2 & 2 & 22.19 & 1.3 & 6 & 5.80 & 1.21 & 1032877677 & a-mannosidase \\
\hline S8* & - & - & - & - & - & - & 3.93 & - & - \\
\hline S9* & - & - & - & - & - & - & 5.11 & - & - \\
\hline S10 & 3 & 3 & 42.77 & 2.8 & 5.91 & 3.87 & 3.43 & 908394288 & a-mannosidase \\
\hline
\end{tabular}

* No protein was identified. $I_{\mathrm{m}}=$ mean spectral intensity
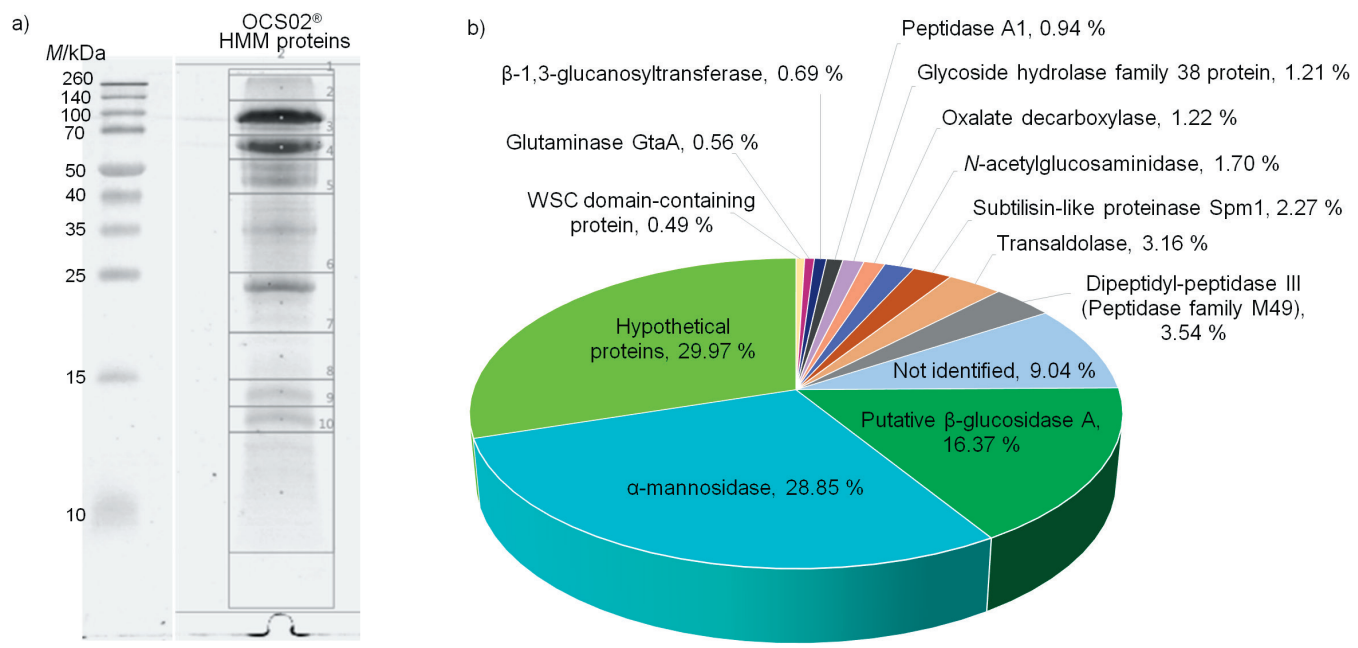

Fig. 2. Protein profile of high molecular mass (HMM) fraction of Ophiocordyceps sinensis fruiting body $\left(\mathrm{OCSO}^{\circledR}\right)$ cold water extract: a) separation of the proteins on SDS-PAGE $15 \% \mathrm{gel}$, and b) distribution (in \%) of the protein fraction of OCS02 ${ }^{\oplus}$ identified by shotgun LC-MS/MS based on the NCBI non-redundant Ophiocordycipitaceae database 
protein, transaldolase and WSC domain-containing protein, are involved in carbohydrate metabolism during the development of $O$. sinensis fruiting body. Study by Park et al. (40) demonstrated that a trypsin-like protease (CMP) purified from Cordyceps militaris has a significant inhibitory activity against human breast MCF7 and bladder 5637 cancer cells. We have identified several proteolytic enzymes including peptidase A1, peptidase family M49 proteins and subtilisin-like proteinase SPM1 in the HMM fraction. These proteases could have contributed to the cytotoxicity of the $\mathrm{OCSO}^{\circledR}$.

$O$. sinensis water extract has been reported to have protective effects on kidneys including decreased proteinuria, enhanced renal functions and inhibited glomerular sclerosis (4). An oxalate decarboxylase (OXDC), an enzyme that mediates the degradation of oxalate, was identified in the HMM fraction of $\mathrm{OCS}^{\circledR}{ }^{\circledR}$ cold water extract. Oxalate, a metabolic end product in humans, if present in excess, can cause calcium oxalate stones or kidney stones. A study has reported that oral administration of oxalate decarboxylase recombinant probiotic bacteria in hyperoxaluria rat models decreased the urinary oxalate level, thereby reducing hyperoxaluria (41). Several oxalate decarboxylase enzyme products such as ALLN-177 (clinicaltrials.gov/ct2/show/results/NCT02289755), Nephure ${ }^{\mathrm{TM}}$ (clinicaltrials.gov/ct2/show/NCT03661216) and OXazyme (clinicaltrials.gov/ct2/show/results/NCT01127087) have undergone clinical trials and demonstrated promising results with significant reduction of oxalate levels in the OXDC-treated groups $(42,43)$. The presence of oxalate decarboxylase in the HMM fraction implicates the potential use of OCSO $2^{\circledR}$ to improve renal functions.

\section{CONCLUSIONS}

The extract from cultivated fruiting bodies of Ophiocordyceps sinensis, $\mathrm{OCSO}^{\circledR}{ }^{\circledR}$, was shown to have promising antioxidant and cytotoxic activity with high content of polysaccharides, proteins and phenolics. The strong superoxide anion radical scavenging of $\mathrm{OCSO}_{2}{ }^{\circledR}$ cold water extract is possibly mainly attributed to its high molecular mass polysaccharide content. The cold water extract inhibited proliferation of lung cancer A549 cells and oestrogen-dependent breast cancer MCF7 cells. The selective cytotoxicity of the high molecular mass (HMM) fraction against A549 cells is associated with the proteins and protein-polysaccharide complexes. Several bioactive proteins with potential cytotoxic properties and kidney protection effects including proteases and oxalate decarboxylase were found in the HMM fraction, implying that this fraction has the potential for development into dietary supplements as adjuvant therapy. Despite that, a more detailed study is required to gain better insights in the biopharmaceutical properties of HMM fraction. Our future study will focus on the investigation of the cytotoxic activity of this fraction in vivo, isolation of protein of interest and investigation of the biopharmaceutical properties and underlying molecular mechanisms of specific proteins for drug discovery.

\section{FUNDING}

This research was supported by Fundamental Research Grant Scheme (FRGS) (FP044-2018A (FRGS/1/2018/SKK08/ UM/02/19)) from Government of Malaysia and Faculty Research Grant (GFP003A,B-2020).

\section{CONFLICT OF INTEREST}

The authors declare there are no conflicts of interest. Szu Ting $\mathrm{Ng}$ is employed by LiGNO Biotech Sdn. Bhd. and Chon Seng Tan is the Technical Advisor to LiGNO Biotech Sdn. Bhd., Balakong Jaya, Selangor, Malaysia.

\section{AUTHORS' CONTRIBUTIONS}

Boon-Hong Kong participated in performing experiments, data collection and analysis, wrote the article and critical revision. Chee-Sum Alvin Yap took part in conducting experiments. Shin-Yee Fung and Muhammad Fazril Mohamad Razif conceived the study, wrote the article and revised the manuscript. Szu-Ting $\mathrm{Ng}$ and Chon-Seng Tan provided the sample material. All authors have read and approved the final version of the article.

\section{ORCID ID}

B.H. Kong (1) https://orcid.org/0000-0003-3255-9960

M.F. Mohamad Razif ( ) https://orcid.org/0000-0002-3951-8136

S.Y. Fung (1) https://orcid.org/0000-0002-9288-7328

\section{REFERENCES}

1. Pegler DN, Yao YJ, Li Y. The Chinese 'caterpillar fungus'. Mycologist. 1994;8(1):3-5.

https://doi.org/10.1016/S0269-915X(09)80670-8

2. Li Y, Wang XL, Jiao L, Jiang Y, Li H, Jiang SP, et al. A survey of the geographic distribution of Ophiocordyceps sinensis. J Microbiol. 2011;49:913-9.

https://doi.org/10.1007/s12275-011-1193-z

3. Seth R, Haider SZ, Mohan M. Pharmacology, phytochemistry and traditional uses of Cordyceps sinensis (Berk.) Sacc: A recent update for future prospects. Indian J Tradit Knowl. 2014;13(3):551-6.

4. Song LQ, Yu SM, Ma XP, Jin LX. The protective effects of Cordyceps sinensis extract on extracellular matrix accumulation of glomerular sclerosis in rats. Afr J Pharm Pharmacol. 2010;4(7):471-8.

5. Siu KM, Mak DHF, Chiu PY, Poon MKT, Du Y, Ko KM. Pharmacological basis of 'Yin-nourishing' and 'Yang-invigorating' actions of Cordyceps, a Chinese tonifying herb. Life Sci. 2004;76(4):385-95.

https://doi.org/10.1016/j.Ifs.2004.07.014

6. Yue K, Ye M, Zhou Z, Sun W, Lin X. The genus Cordyceps: A chemical and pharmacological review. J Pharm Pharmacol. 2013;65(4):474-93.

https://doi.org/10.1111/j.2042-7158.2012.01601.x 
7. Hopping KA, Chignell SM, Lambin EF. The demise of caterpillar fungus in the Himalayan region due to climate change and overharvesting. PNAS. 2018;115(45):11489-94. https://doi.org/10.1073/pnas.1811591115

8. Lo HC, Hsu TH, Tu ST, Lin KC. Anti-hyperglycemic activity of natural and fermented Cordyceps sinensis in rats with diabetes induced by nicotinamide and streptozotocin. Am J Chin Med. 2006;34(5):819-32. https://doi.org/10.1142/S0192415X06004314

9. Lo HC, Hsieh C, Lin FY, Hsu TH. A systematic review of the mysterious caterpillar fungus Ophiocordyceps sinensis in DongChongXiaCao (冬蟲夏草 Dōng Chóng Xià Cǎo) and related bioactive ingredients. J Tradit Complement Med. 2013;3(1):16-32.

https://doi.org/10.1016/S2225-4110(16)30164-X

10. Singh KP, Meena HS, Negi PS. Enhancement of neuromuscular activity by natural specimens and cultured mycelia of Cordyceps sinensis in mice. Indian J Pharm Sci. 2014;76(5): 458-61.

11. Wang J, Kan L, Nie S, Chen H, Cui SW, Phillips AO, et al. A comparison of chemical composition, bioactive components and antioxidant activity of natural and cultured Cordyceps sinensis. LWT - Food Sci Technol. 2015;63(1):2-7. https://doi.org/10.1016/j.lwt.2015.03.109

12. Fung SY, Cheong PCH, Tan NH, Ng ST, Tan CS. Nutrient and chemical analysis of fruiting bodies of a cultivar of the Chinese caterpillar mushroom, Ophiocordyceps sinensis (Ascomycetes). Int J Med Mushrooms. 2018;20(5):459-69.

https://doi.org/10.1615/IntJMedMushrooms.2018026252

13. Fung SY, Lee SS, Tan NH, Pailoor J. Safety assessment of cultivated fruiting body of Ophiocordyceps sinensis evaluated through subacute toxicity in rats. J Ethnopharmacol. 2017;206:236-44.

https://doi.org/10.1016/j.jep.2017.05.037

14. Yap ACS, Li X, Yap YHY, Mohamad Razif MF, Jamil AHA, Ng ST, et al. Immunomodulatory properties of water-soluble polysaccharides extracted from the fruiting body of Chinese caterpillar mushroom, Ophiocordyceps sinensis cultivar OCS02 ${ }^{\circledast}$ (Ascomycetes). Int J Med Mushrooms. 2020; 22(10):967-77.

https://doi.org/10.1615/IntJMedMushrooms.2020036351

15. Bradford MM. A rapid and sensitive method for the quantitation of microgram quantities of protein utilizing the principle of protein-dye binding. Anal Biochem. 1976;72(12):248-54.

https://doi.org/10.1016/0003-2697(76)90527-3

16. DuBois M, Gilles KA, Hamilton JK, Rebers PA, Smith F. Colorimetric method for determination of sugars and related substances. Anal Chem. 1956;28(3):350-6.

https://doi.org/10.1021/ac60111a017

17. Singleton VL, Rossi JA. Colorimetry of total phenolics with phosphomolybdic-phosphotungstic acid reagents. Am J Enol Vitic. 1965;16:144-58.
18. Benzie IFF, Strain JJ. The ferric reducing ability of plasma (FRAP) as a measure of "antioxidant power": The FRAP assay. Anal Biochem. 1996;239(1):70-6.

https://doi.org/10.1006/abio.1996.0292

19. Siddhuraju P, Becker K. The antioxidant and free radical scavenging activities of processed cowpea (Vigna unguiculata (L.) Walp.) seed extracts. Food Chem. 2007;101(1):10-9. https://doi.org/10.1016/j.foodchem.2006.01.004

20. Cos P, Rajan P, Vedernikova I, Calomme M, Pieters L, Vlietinck AJ, et al. In vitro antioxidant profile of phenolic acid derivatives. Free Radic Res. 2002;36(6):711-6. https://doi.org/10.1080/10715760290029182

21. Yap HYY, Fung SY, Ng ST, Tan CS, Tan NH. Shotgun proteomic analysis of tiger milk mushroom (Lignosus rhinocerotis) and the isolation of a cytotoxic fungal serine protease from its sclerotium. J Ethnopharmacol. 2015;174:437-51.

https://doi.org/10.1016/j.jep.2015.08.042

22. Kong BH, Teoh KH, Tan NH, Tan CS, Ng ST, Fung SY. Proteins from Lignosus tigris with selective apoptotic cytotoxicity towards MCF7 cell line and suppresses MCF7-xenograft tumor growth. PeerJ. 2020;8:e9650.

https://doi.org/10.7717/peerj.9650

23. IBM SPSS Statistics for Windows, v. 22.0, IBM Corp. Armonk, NY, USA; 2013.

24. Wang $Y, X u$ B. Distribution of antioxidant activities and total phenolic contents in acetone, ethanol, water and hot water extracts from 20 edible mushrooms via sequential extraction. Austin J Nutri Food Sci. 2014;2(1):1009.

25. Kong BH, Tan NH, Fung SY, Pailoor J, Ng ST, Tan CS. Nutritional composition, antioxidant properties and toxicology evaluation of the sclerotium of the tiger milk mushroom Lignosus tigris cultivar E. Nutr Res. 2016;36(2):174-83. https://doi.org/10.1016/j.nutres.2015.10.004

26. Yap YH, Tan NH, Fung SY, Aziz AA, Tan CS, Ng ST. Nutrient composition, antioxidant properties, and anti-proliferative activity of Lignosus rhinocerus Cooke sclerotium. J Sci Food Agric. 2013;93(12):2945-52.

https://doi.org/10.1002/jsfa.6121

27. Shen W, Song D, Wu J, Zhang W. Protective effect of a polysaccharide isolated from a cultivated Cordyceps mycelia on hydrogen peroxide-induced oxidative damage in PC12 cells. Phytother Res. 2011;25(5):675-80.

https://doi.org/10.1002/ptr.3320

28. Yan JK, Li L, Wang ZM, Leung PH, Wang WQ, Wu JY. Acidic degradation and enhanced antioxidant activities of exopolysaccharides from Cordyceps sinensis mycelial culture. Food Chem. 2009;117(4):641-6.

https://doi.org/10.1016/j.foodchem.2009.04.068

29. Schiller JH, Kao C, Bittner G, Harris C, Oberley TD, Meisner LF. Establishment and characterization of a SV40 T-antigen immortalized human bronchial epithelial cell line. In Vitro Cell Dev Biol - Animal. 1992;28:461-4.

https://doi.org/10.1007/BF02634125 
30. Schiller JH, Sabatini L, Bittner G, Pinkerman CL, Mayotte J, Levitt $M$, et al. Phenotypic, molecular and genetic-characterization of transformed human bronchial epithelial-cell strains. Int J Oncol. 1994;4(2):461-70.

https://doi.org/10.3892/ijo.4.2.461

31. Lee SH, Jaganath IB, Wang SM, Sekaran SD. Antimetastatic effects of Phyllanthus on human lung (A549) and breast (MCF-7) cancer cell lines. PLoS ONE. 2011;6(6):e20994.

https://doi.org/10.1371/journal.pone.0020994

32. Wu X, Zhu H, Yan J, Khan M, Yu X. Santamarine inhibits NF$\kappa B$ activation and induces mitochondrial apoptosis in A549 lung adenocarcinoma cells via oxidative stress. BioMed Res Int. 2017;2017:4734127.

https://doi.org/10.1155/2017/4734127

33. Maryam A, Mehmood T, Yan Q, Li Y, Khan M, Ma T. Proscillaridin A promotes oxidative stress and ER stress, inhibits STAT3 activation, and induces apoptosis in A549 lung adenocarcinoma cells. Oxid Med Cell Longev. 2018;2018:Article ID 3853409.

https://doi.org/10.1155/2018/3853409

34. Vilariño M, García-Sanmartín J, Ochoa-Callejero L, LópezRodríguez A, Blanco-Urgoiti J, Martínez A. Macrocybin, a natural mushroom triglyceride, reduces tumor growth in vitro and in vivo through caveolin-mediated interference with the actin cytoskeleton. Molecules. 2020;25(24):6010. https://doi.org/10.3390/molecules25246010

35. Wu KM, Chi CW, Lai JC, Chen YJ, Kou YR. TLC388 induces DNA damage and $\mathrm{G} 2$ phase cell cycle arrest in human nonsmall cell lung cancer cells. Cancer Control. 2020;27(1):1-13. https://doi.org/10.1177/1073274819897975

36. Song D, He Z, Wang C, Yuan F, Dong P, Zhang W. Regulation of the exopolysaccharide from an anamorph of Cordyceps sinensis on dendritic cell sarcoma (DCS) cell line. Eur J Nutr.
2013:52:687-94.

https://doi.org/10.1007/s00394-012-0373-x

37. Zhang W, Yang J, Chen J, Hou Y, Han X. Immunomodulatory and antitumour effects of an exopolysaccharide fraction from cultivated Cordyceps sinensis (Chinese caterpillar fungus) on tumour-bearing mice. Biotechnol Appl Biochem. 2005;42(1):9-15.

https://doi.org/10.1042/BA20040183

38. Xu X, Yan HChen J, Zhang, X. Bioactive proteins from mushrooms. Biotechnol Adv. 2011;29(6):667-74.

https://doi.org/10.1016/j.biotechadv.2011.05.003

39. Yap HYY, Fung SY, Ng ST, Tan CS, Tan NH. Genome-based proteomic analysis of Lignosus rhinocerotis (Cooke) Ryvarden sclerotium. Int J Med Sci. 2015;12(1):23-31.

https://doi.org/10.7150/ijms.10019

40. Park BT, Na KH, Jung EC, Park JW, Kim HH. Antifungal and anticancer activities of a protein from the mushroom Cordyceps militaris. Korean J Physiol Pharmacol. 2009;13(1):4954.

https://doi.org/10.4196/kjpp.2009.13.1.49

41. Zhao C, Yang H, Zhu X, Li Y, Wang N, Han S, et al. Oxalate-degrading enzyme recombined lactic acid bacteria strains reduce hyperoxaluria. Urology. 2018;113:253.e1-7. https://doi.org/10.1016/j.urology.2017.11.038

42. Dindo M, Conter C, Oppici E, Ceccarelli V, Marinucci L, Cellini B. Molecular basis of primary hyperoxaluria: clues to innovative treatments. Urolithiasis. 2019;47(1):67-78. https://doi.org/10.1007/s00240-018-1089-z

43. Quintero E, Bird VY, Liu H, Stevens G, Ryan AS, Buzzerd S, et al. A prospective, double-blind, randomized, placebo-controlled, cross-over study using an orally administered oxalate decarboxylase (OxDC). Kidney360. 2020;1(11)1284-90. https://doi.org/10.34067/KID.0001522020 